\title{
The Comprehensible Output Hypothesis and Self-directed Learning: A Learner's Perspective ${ }^{1}$
}

Yu Liming

\begin{tabular}{ll}
\hline $\begin{array}{l}\text { In the course of his diary study dealing } \\
\text { with communication strategies, the writer }\end{array}$ & $\begin{array}{l}\text { dent and indispensible role to play. } \\
\text { Swain's thesis has proved to be of rele- } \\
\text { of this paper has found that the way of }\end{array}$ \\
$\begin{array}{l}\text { vance to the writer's experience as a self- } \\
\text { acquiring a language is not merely as sim- }\end{array}$ & $\begin{array}{l}\text { directed learner. This paper discusses in } \\
\text { detail the significance to language acquisi- }\end{array}$ \\
Krashen's Input Hypothesis (1985) claims. & tion of pushing for comprehensible output. \\
Swain's Comprehensible Output Hypoth- & Three issues are discussed: (1) comprehen- \\
esis (1985) maintains that the development & sible output and negative input; (2) com- \\
of a learner's communicative competence & prehensible output and incomprehensible \\
does not merely depend on comprehensible & $\begin{array}{l}\text { output; (3) comprehensible output and } \\
\text { input: the learner's output has an indepen- }\end{array}$
\end{tabular}

Diaries have frequently been used by second language learners (Bailey, 1980 ) to discover affective factors influencing second language learning (Schumann \& Schumann, 1977). Rivers (1983) kept a diary to reflect upon her experience in learning new languages. She has pointed out that second language learners can use diary studies to develop strategies of language-in-use to meet the needs of communication in an authentic communication setting. Therefore in September 1988, I started a diary to promote my own communicative competence.

I started to learn English at the age of 15 at a senior high school. I could be counted as a successful learner in my country-The People's Republic of China. After finishing high school, I passed highly competitive examinations, and was admitted into the B.A. programme and the M.A. programme in the English Language and Literature Departments of Beijing University and Fudan University respectively - the two most prestigious comprehensive universities in China (There was a ten-year interruption between the two programmes because of the havoc of "The Cultural Revolution" that lasted from 1966 to 1976). Upon graduation from Fudan, I taught English as a foreign language in a leading university of science and technology for a few years. I translated Philip Roth's novels into Chinese and some pamphlets into English, and my translation works were officially published. However, after I arrived in Canada about a year ago, I would now and then find myself unable to cope with basic communication needs 
in this English-speaking environment. For example, once I got on a bus, and I did not have enough change with me. I was not able to pay the driver because the passenger standing nearby refused to "exchange" my five-dollar bill as I had asked. I could not help but wonder how the nearby passenger could not have understood "exchange" in that context. I suspected that (s)he did not have change, did not want to be bothered or had some excuse for not responding. Only after consulting a native speaker the next day did I understand that I should have asked the passenger to "change" rather than "exchange" the five-dollar bill (Journal: Dec. 7, 1988). On another occasion, I bought five tapes in a bookstore. I needed two receipts-one for two tapes and another one for the rest. But it took quite a long time for the shop assistant to understand what I was talking about because I had used the word "invoice" instead of "bill" or "receipt" (Journal: Jan. 8, 1989).

Littlewood (1987) constructed a model of advanced language learners' language development, in which he divided communication needs into pragmatic needs and social needs. According to him, the former refers to "the desire to communicate effectively in a pragmatic sense", the latter to "the desire to communicate appropriately in a social sense". The division of communication needs into pragmatic and social needs in Littlewood's model is significant. So far as advanced learners are concerned, occasions like the aforementioned examples in the bus or in the bookstore where their communicative competence is not strong enough to cope with pragmatic needs are relatively few. As has been shown throughout my journal entries, problems an advanced learner often encounters are problems of social needs on the interpersonal level. Let me quote my journal to illustrate:

. . one summer morning I met a professor with whom I had taken a course in the previous semester. I had not seen him for quite a while. As customary in my culture, I greeted him to express my friendliness. He used to look pale, but that day he really looked well with a radiant face. I said to him: "Hello, Prof. X, You are looking much better today." This professor looked at me and asked: "Am I? In what ways?" I was at a loss as to what to say, for I did not know whether it was appropriate to tell him that he used to look pale as I observed it. After a moment's silence, he asked again: "Do you mean I am formally dressed?" It was a fact that he used to dress casually and today he was formally dressed. But in my culture, it was very inappropriate for a junior or subordinate (such as a student) to comment on the dress of a senior or superior (such as a teacher). I was really embarrassed by this misunderstanding. In order to get over the embarrassment, I replied: "Your face is glowing with radiance." The laughter from a secretary made me realize that I had gone from bad to worse in my effort to make the communication a success. (Sept. 27) 
Note that I encountered the above-mentioned communication problems after I had already lived in two English-speaking countries for one and a half years (I stayed first in Australia from March 1987 to December 1988 and then in Canada from January 1988 to now). This means that so far as adult learners (even an advanced learner like myself) are concerned, mere exposure to the target language does not automatically lead to native-like communicative competence. They need to heighten their awareness of pragmatic and social needs as suggested in Littlewood's model so that they will be continually motivated to strive for such communicative competence. Therefore, recording these problems in my journal and reflecting upon them every day have provided me with a strong impetus for identifying and overcoming gaps in my communicative competence.

\section{A Theoretical Justification for My Self-directed Learning: the Comprehensible Output Hypothesis}

As soon as I began my diary study, I was, so to speak, haunted by a spectre-Krashen's Monitor Model. According to Krashen, my project would basically fall into the category of "learning" as opposed to "acquisition". Krashen argues that conscious learning is possibly unnecessary for most language acquirers, except for certain aspects of language use such as formal speaking or writing (Krashen, 1978). Moreover, conscious learning cannot become the central process of acquisition, which is a subconscious or automatic process (Krashen, 1982). Krashen claims that "Acquisition occurs, according to the input hypothesis, when acquirers understand input for meaning, not when they produce output and focus on form" (Krashen, 1982: 117). By contrast, the literature on learning strategies focuses on learners' conscious efforts that are directed towards production of output as well as comprehension of input (Rubin, 1987; Chamot, 1987; Dickinson, 1987; Holec, 1985). So if Krashen were right, what would be the theoretical underpinnings for what I was doing?

At the inception, I derived theoretical "courage" from Swain's Comprehensible Output Hypothesis (Swain, 1985). Just as Dell Hymes (1974) put forward the concept of communicative competence in deliberate contrast to Chomsky's concept of linguistic competence, so Swain advanced the Comprehensible Output Hypothesis in deliberate contrast to Krashen's Comprehensible Input Hypothesis. Swain points out:

Simply getting one's message across can and does occur with grammatically deviant forms and sociolinguistically inappropriate language. Negotiating meaning needs to incorporate the notion of being pushed toward the delivery of a message that is not only conveyed, but that is conveyed precisely, coherently, and appropriately. Being 'pushed' in output, it seems to me, is a concept parallel to that of the $i+1$ comprehensible input (248-249). 
In my situation of self-directed learning, I have to 'push' myself to comprehensible output, that is, to meet the social and pragmatic needs in this target language environment. In the following three sections that explicate the significance of the Comprehensible Output Hypothesis to my self-directed learning, I will concentrate on three issues: (1) comprehensible output and negative input; (2) comprehensible output and incomprehensible output; (3) comprehensible output and comprehensible input. In considering each issue, it is important to recall what Swain (1985) sees as the critical role of comprehensible output:

... using the language as opposed to simply comprehending the language may force the learner to move from semantic processing to syntactic processing." (p249)

\section{Pushing for Comprehensible Output Is Pushing for Negative Input}

According to Schachter (1984) "negative input"

can be roughly characterized as information provided to the learner that her utterance was in some way deviant or unacceptable to the native speaker, i.e., that it wasn't understandable, wasn't grammatically correct, wasn't situationally appropriate. (p168)

She further emphasizes that this is a universal input condition. Vigil and Oller (1976) contend that learners will most likely continue to improve their grammar if they are getting negative reactions and/or corrective feedback from speakers of the target language. However, when the feedback is predominantly positive, their level tends to fossilize. In other words, in the absence of negative input, language learning/acquisition cannot possibly take place. However, in the light of my experiences in self-directed learning, such negative input is not readily available. That is to say, native speakers will attend to meaning rather than form. In my journal I have recorded:

My officemate Elizabeth was briefly away and a man came to our office to look for her. I said: "She has been away to fetch water." I felt the expression was awkward. Then I added: "She has gone for water." I still felt uncomfortable with the sentence. When Elizabeth came back, I asked her how to say it. She said: "I would say "she just went to get some water." "At this point it so happened that the man came back to our office again. I asked him: "Why didn't you correct my error just now?" He replied: "Since I understood what you meant, why should I bother? In fact I am used to hearing no-soidiomatic sentences." (Oct. 27)

This man's attitude towards non-native speakers' linguistic inaccuracies is consistent with Elizabeth's attitude which was reflected in a conversation 
that I had with her recorded in my journal entry of Oct. 13. She said she didn't care about minor inaccuracies in non-native speakers' utterances just as she didn't care about her own minor inaccuracies in her French. In authentic communication, attention naturally turns to meaning. As a matter of fact, it is difficult to pay attention to meaning and form at the same time (Stern, 1983: 402). Moreover, I would like to point out that there is a social problem involved here: correcting someone could imply a position of superiority. Therefore it is awkward for native speakers to do so. Besides, the need for correction is called into question in view of linguistic variability that characterizes a multi-cultural, multi-lingual society like Toronto where I live. For all these reasons, the native speaker seems tolerant of inaccuracies of non-native speakers' utterances.

On the other hand, mention must be made of the fact that in the examples cited above I was understood. This is a different case from the pragmatic problem of change/exchange, receipt or bill/invoice or the social problem with Prof. X, where I experienced a communication breakdown. So what is at issue in the case of avoiding the consequences of native speakers' "inaccuracy tolerance" is my drive for perfection, that is, for native-like communicative competence. It is this drive that pushes me toward comprehensible output and sometimes furnishes me with negative input in the natural communication setting. Consider my journal again:

In a short conversation with Elizabeth, I made the following three mistakes:

1. "I cannot follow the reading" when I meant to say "I cannot keep up with the reading."

2. "All his jobs are full" when I actually meant to say "all his jobs are taken."

3. "It wasted me a lot of time" when I meant to say "It wasted a lot of my time."

I was not aware of the first mistake until Elizabeth asked me to clarify my meaning. I recognized the second mistake when I noticed a puzzled look across her face. So I stopped to check with her. As to the third mistake, I was aware of it as soon as it was uttered and then I corrected it myself. (Oct 13)

From the above, we have seen the first error is corrected by explicit correction. The third example is more a performance than a competence error, which was readily corrected by virtue of monitoring my output. But in the second example, I was not only monitoring my output, but also keeping track of its effects. It was the feedback from the interlocutor (in this case it was Elizabeth's puzzled look) that made me aware of this competence error. Here, whether the error is self-corrected or identified through extralinguistic context such as puzzled looks, the role of monitoring output is indispensable in both cases. My experience in my self- 
directed learning has shown that so far as negative input is concerned, the onus is on the learner to infer (as in the second example) in a genuine communication setting rather than being supplied by the native speakers (as in the first example). In Krashen's Model, Monitor (not monitor) is defined as a process that "edits one's own output" (1982: 15). Morrison and Low (1983) criticize this narrow use of the concept "monitor" and call for recourse to the original expanded sense. They define it as a basic psychological process, "a critical faculty" which "gives awareness of what has been created, making it possible to check, either before or after articulation, for the frequent slips of the tongue, grammar errors, social infelicities and other deviations from intention that characterize normal speech" (p.228). In this sense, learners should develop such a critical awareness so that they will be in a position to infer negative input. In the second example, if I had been less critically aware of the effects of what I had said, I might not have been able to detect the error from Elizabeth's puzzled looks.

As has been stated earlier, for various reasons native speakers do not readily supply negative input. However, pushing for comprehensible output can lead you later to seek negative input from native speakers. For instance, in the natural communication setting, I might not have the opportunity to check with the native speaker certain utterances that I had produced. However, I would try to remember those dubious utterances and check them with native speakers later. I remember once during a telephone conversation, I tried to express the idea that "I am no longer so busy as before". I said "things are eased out now". I did not feel quite happy with 'ease out', but could not possibly have checked with the speaker over the telephone. However, I memorized the utterance and consulted some other native speakers afterwards. I learned that 'ease up' is the right expression. My journal records more examples in which I used the strategy of recall and reflection:

When I saw Annette in the corridor, I said "hey, you are in a new hairstyle." I had a hunch that the sentence was wrong. Should it be "You have a new hairstyle today?" Later, I asked a native speaker and my hypothesis was confirmed. But I recall Annette did not show any sign that would indicate I had uttered an ungrammatical sentence. (Jan. 11)

Sometimes in a conversation or in the midst of narration, I had to keep communication going by using whatever word or expression came to mind although I was not in the least certain of its correctness or appropriateness. However, I would try to verify them as soon as I had a chance. My journal records: 
On Saturday (Feb. 4) I had a conversation with John while we were waiting for Elizabeth. In the course of my conversation, I could not recall the proper word to denote 'the noise of opening and closing newspaper'. I used 'crunching of newspaper'. John did not point that mistake out to me. But as I already knew that in a real communication setting, reticence on the part of the interlocutor did not mean his/her approval of the usage of the speaker's utterance, I asked John about my use of 'crunching of newspapers' after we sat down at a table. He told me I should have used 'rustling' instead. (Feb. 4th)

As for inferencing of implied negative input, my enhanced knowledge of learning strategies which may well be called metacognitive knowledge (Wenden, 1986) has proved to be a great asset. This has already been demonstrated in the journal entries of Jan. 11 and Feb. 4 cited above. One more example further illustrates the point:

In the Colloquium Class, I said to Roy: "I intend to drop the party." Roy said: "What?" Having consciously applied learning strategies so long, I immediately recognized this was a clarification request rather than a request for me to repeat the sentence. So I immediately realized that my output was not comprehensible. Then I thought over the sentence again. The only possible mistake I could have made was 'drop' in this context. So I tried to confirm my hypothesis with him: "Is it correct to say 'drop the party?"' Roy answered: "You can say "drop a class', but not a party." At this moment of writing the journal, I seem to realize that I used 'drop the party' just because I had heard 'drop the class', hence making an error of overgeneralization. (Feb. 17)

If I had treated Roy's 'what' as a request for information, I would have repeated the sentence again and he would have replied: "It's up to you", or "I hope you can go." and so on. The result would have been further consolidation of the erroneous use of 'drop'.

So as the above examples have demonstrated, "push and you are supplied with negative input" can be an adage for self-directed learners.

\section{Pushing for Comprehensible Output: Incomprehensible Output Becomes Comprehensible Output}

In Swain (1985) there is no such term as "incomprehensible output". But since we have 'comprehensible output', there must be incomprehensible output. Then what is it? I assume since Swain has defined 'comprehensible output' as "a message conveyed precisely, appropriately and coherently" (249), whatever output fails to meet the three criteria is incomprehensible output. The reason why Swain has not used the term is prob- 
ably that, as has been stated earlier, "comprehensible output" is an analogy based on Krashen's "comprehensible input". But in Krashen's framework, "incomprehensible input" is an important, clearly defined term. It does not mean the structure in question is at fault, but that it is beyond the learner's current level of competence. Incomprehensible output, however, cannot be viewed in the same vein. That is to say, it is incomprehensible not because the hearer is responsible for the problem, but because the speaker is responsible. Then how can adult self-directed learners produce comprehensible output and avoid incomprehensible output? Could it be done merely by 'understanding input for meaning' as Krashen has suggested? Many examples in my journal entries show that at least in so far as adult second language learners are concerned, understanding input for meaning is not enough. They must grasp the structure of the input.

One October journal entry recorded that in a conversation with a mechanic of the Bell Telephone Company, I wrongly used "fix" and "establish" for "install" as in "install a telephone". In the case of using the word "fix", there was a communication breakdown, which made me aware of the mistake. But when I substituted it with the word "establish", I got my intended message across. Therefore, I did not realize that "establish" was also misused for that occasion until one day I had a chance to talk with Elizabeth about it. She told me 'install' would be the correct word. Then she added: "To be more appropriate, you had better say "have the phone installed' ". However, in retrospect, up to this point I had merely been engaging in semantic processing of the desired form "have . . . installed". Three days after the talk with Elizabeth, I found myself in trouble with the expression again when I had a conversation with a friend. My diary notes:

I asked Mr. Yang: "Do you still live at Bathurst?" "Yes," he answered. "Have you. . ." my speech stuck there: I was searching for the expression "install your telephone", but the expression "establish' was forcing itself on me. . . (Nov. 18)

What was particularly worthy of note is that in the journal entry quoted above, I still was not aware that it was not "install the telephone", but "have the telephone installed" that I should be struggling for. It was only after I reviewed my journal a few days later that I realized that I should have used the pattern "have . . . installed". I think my failure to produce this correct form was due to the fact that the Chinese equivalent for "install the telephone" also implies "have the telephone installed" in English (in fact there is no corresponding structure in Chinese for "have . . . installed"). It was my grammatical analysis of the structure of this input that was made when I was reviewing my journal that led me to realize "install the telephone" used on the above occasion was incomprehensible output. 
It is quite clear that the process of the production of the comprehensible output "have the telephone installed" involved a transition from semantic processing of input to syntactic processing. Such a transition would have been infeasible without the conscious efforts on my part.

In explaining why the French immersion students in her study failed to achieve native speaker-like grammatical competence, Swain pointed out that there was little social or cognitive pressure on these students to produce language that reflected more appropriately or precisely their intended meaning, that is, there was no push for them to analyze further the grammar of the target language because their current output appeared to succeed in conveying their intended meaning (Swain, 1985: 249). The example cited above has shown that advanced learners like myself also need to do grammatical analysis of the input they have received. Consider one more example:

I met Ruth. She was told to move her stuff to another room as the office she was using would become the printing room. I asked: "Where is the office you were directed to move to?" I immediately sensed that the word "directed" was not properly used, but in Ruth's reply I found the expression that I needed but could not produce. She said: "They want to move us to the printing room." I only knew "move something", so I dare not use "move someone". If I had known this structure, I would have asked Ruth in this way: "Where is the office you will be moved to?" (Dec. 14)

As has been shown in the above example, as I was not satisfied with my output ". . . you were directed to move. ..", I was very sensitive to Ruth's input. In fact, her input "they wanted to move us" was an implied correction of my output, which led me to formulate a syntactic rule "move + human as the object". My understanding of this syntactic rule was derived from the comparison between the incomprehensible output "direct us to move" and the comprehensible input "move us". Therefore, with the help of this syntactic rule, I managed to identify and drop the incomprehensible output "directed us to move" (as is used on the occasion described above) in my subsequent communicative performance.

Therefore, it seems to me that syntactic rather than semantic processing of input for structure may be essential for correcting incomprehensible output. In the light of my diary study, pushing for comprehensible output by eliminating incomprehensible output takes place in the following four situations: (1) when I am developing an ability to use words correctly in context (the "fix" example); (2) when I am making a critical comparison between my own output and native speakers' input (the "move us" example); (3) when I am making repeated attempts at using expressions newly learned to replace old ones (the "ease up" example where, in attempting to use this phrasal verb to replace "I am not so busy", I erred in using 
"ease out", but my attention to the composition of the structure of this phrase led me to awareness of the incomprehensible output "ease out"). (4) when I am testing out new hypotheses. My Feb. 17 journal cited earlier has furnished such an example. The reason I said "drop the party" was because I had heard people say "drop the class". The new linguistic data (drop the class) induced the wrong hypothesis (drop the party). The example has shown that I still needed practice to test my hypotheses about the range of use of the word "drop", confirming the right and correcting the wrong. It is evident that in all these situations attention to the form of the target language data was necessary to eliminate incomprehensible output in the course of pushing for comprehensible output.

Theoretically speaking, comprehensible output in Swain's theoretical framework is treated more as a process than as a product. It is a product at a given point in time. However, diachronically speaking, the learners' comprehensible output represents their developmental process of interlanguage system which, theoretically, should end up in native speaker-like proficiency. In this sense, the overall output produced by a learner when he or she is at a lower level of competence is relatively less "comprehensible" than that produced when he or she has reached a higher level of competence. Therefore, the process of pushing for comprehensible output may be seen as a process of eliminating incomprehensible output.

According to Krashen's Comprehensible Input Hypothesis, it seems production of native-like error-free output is related only to understanding language that contains $i+1$ structures, not related to error correction. Krashen has taken as the starting point his assumption that adults' acquisition is a process "similar, if not identical to the way children develop ability in their first language." (1982: 10). However, the fact is an adult foreign language learner at least already speaks a language. Personally, I can hardly imagine how the adult's way of developing his/her competence can be "identical" to that of a child's. In the light of my journal entries, most of my errors come from L1 interference. For example, the incomprehensible output "establish a telephone" was induced by the Chinese equivalent for 'install'.

To reinforce this point I mention an interesting, regularly recurring phenomenon identified in the journal entries: At the start of a conversation when my monitor does not seem to be ready to function, I am almost bound to make this type of error. Examine the following journal entry:

I saw Mela in the computer-room. I said to her: "Ah, it is you! I saw you from your behind and was not sure whether it was really you." We have known each other for a time. So she pointed out to me: "You should have said "looked at you from behind you." She added: "You know the connotation of the word "behind"" No sooner had she said this than I realized what a serious mistake I had made! I certainly 
known the denotation of the word 'behind' used as a noun. . . (Feb.

13)

The error was due to the fact that I phrased the idea in Chinese and then was 'subconsciously' translating it into English. If the erroneous English sentence were put back into Chinese, it would be a perfect sentence (The corresponding Chinese syntactic structure is 'from your behind' rather than 'from behind you'). Although I know all along that I must not think in Chinese, I cannot help doing such 'subconscious translation' in actual communication. This has demonstrated that second language learners (advanced learners included) have a tendency to remain in the stage of semantic processing. To avoid incomprehensible output induced by negative interference from $\mathrm{L} 1$, the learner must engage in syntactic processing. For instance, the analysis of the structural differences between Chinese and English in the expression for "look . . from behind you" helped me to identify my incomprehensible output "from your behind". In the light of my diary study, such errors are very difficult to eradicate. Without making strenuous efforts to push for comprehensible output, communication in the sense of getting a message across could only incur the danger of reinforcing such incomprehensible output (Higgs and Clifford, 1982).

\section{Pushing for Comprehensible Output is Pushing for Comprehensible Input}

According to Krashen's Input Hypothesis, understanding input for meaning naturally leads to acquisition of the structure of the language contained in the input. In fact, he is advocating that understanding input for meaning is understanding input for structure. Krashen (1982: pp. 8789) cited his personal experience in teaching the progressive tense ${ }^{2}$ in the English language to illustrate this point. He gave three sentences in which the progressive tense is used:

1. What is the noise from the other room? (John is playing the violin.)

2. What's John doing this summer? (He is playing the violin for the local symphony.)

3. What's John doing tomorrow? (He's playing the violin in the talent show.)

Krashen claimed that his advanced students had acquired the progressive tense without learning the rule and the evidence of acquisition was that they could tell the three different meanings expressed by the progressive tense in the three sentences (In (1) an ongoing action is expressed; in (2), the action started some time ago in the past and may or may not be taking place at the moment; and in (3), the future time is expressed). But in the light of my personal experiences, it is very doubtful that these advanced learners in question can really use the progressive tense in all cir- 
cumstances. I myself can also tell the differences in meaning expressed by the progressive tense in these three sentences, but in some cases, I could not use the tense properly. Consider the following example:

Four hours ago, I had a talk with Elizabeth. She told me it had taken her a year to write the qualifying research paper. I asked: "You did work that year?" I was really dissatisfied with this sentence. Suddenly I heard her say "Yes, I was working that year." So I knew that the past progressive aspect should have been used. (Oct. 13th26th)

This example has shown that a clearer understanding of the progressive aspect is achieved not when input containing this structure is directed to the learner, but when the learner is pushing for such a structure in his output. I would argue that comprehensible output plays an independent and indispensable role in understanding and assimilating input. Long (1982: 211) has pointed out that in addition to the method of modifying input itself as suggested by Krashen there are three other ways in which input can be made comprehensible: (1) by use of the linguistic and extralinguistic context, (2) through orienting conversation to the "here and now", (3) modifying the interactional structure of conversation through such devices as self- and other-repetition, confirmation and comprehension checks and clarification requests. However, it seems to me that the starting point for proposing these strategies is the comprehension-acquisition belief which excludes the role of output in language acquisition. In this sense, Swain's Comprehensible Output Hypothesis deserves our special attention. Take the example recorded in my Journal:

I said to the social worker over the telephone: "Would you leave a message when you try to contact me? This is because I am a student and the secretary in my department will not try to find me and ask me to answer the phone call." After the conversation, I felt unsatisfied with my "output". I asked the secretary how to express the situation. She told me I could have answered "the secretary does not take the student's call. (Oct. 13-26)

I must have heard the expression "take somebody's call" on a few occasions. I remember I had come across it on a notice posted in the department. So it seems that the phrase could count as comprehensible input. However, for quite a long time I still could not produce it in actual communication. But pushing for comprehensible output as I did in this case, I managed to bring "take somebody's call" from the passive repertoire to the active. The process of pushing for comprehensible output involves a circular movement: you start from pushing for comprehensible output where you are monitoring your output and keeping track of its feedback. The next stage is that you push for input which is the correction 
of or improvement on your incomprehensible output. Finally you go back to the starting point of pushing for comprehensible output again where you are testing out your new hypothesis. So far as advanced learners are concerned, as they already have at least a working knowledge of grammar and vocabulary to cope with communication needs, they are likely to "fossilize" at one particular proficiency level if they are content with the so-called compensatory communication strategies such as paraphrase or circumlocution as in the case of my circumlocution for "take the call" to cope with communication needs. If they do not make a conscious effort to improve their communicative performance, they are unlikely to improve their competence.

As Gregg (1984: 88) has pointed out: if output is available as input, and if Monitoring can increase the incidence of correct utterances of a given structure, then it would seem output is being used to further acquisition. In this sense, we see that one's own comprehensible output can serve as useful comprehensible input. To illustrate this point, note how I learned/ acquired the word "hi" during the past four months. I never came across the expression during the years of my formal instruction. It did not become comprehensible input until I started my diary. My journal records:

Met Prof. X. I greeted him: "Good afternoon." He responded: "Hi!" His greeting started a chain of thought in my mind. Since arrival in Canada 9 months ago (nay, since I left China 16 months ago), I must have heard this expression lots of times. However, surprisingly enough, I never even was aware of the existence of this expression. Only a few days ago, I for the first time saw this word in print in Prof. Y's computer mail message. The word struck me as novel at first. Then I guessed its meaning, in the process of which I vaguely remembered hearing it before. Yesterday, I read a passage from J. Norrish's book which goes as follows: "For example, in such basic areas as greeting, students should be aware of the differences between 'good morning', 'Hello' and 'Hi'. Over-use of the most formal 'good morning' would be as inappropriate as the use of "Hi" in the wrong circumstances" (Norrish, 1983: 5). The interesting point is that even after I became aware of the differences, I still could not use it during today's exchange of greetings with Prof. X. (Oct. 2)

However, as my journal has shown, being "aware of the differences" does not mean that $I$ already comprehend the use of these greetings. My Journal entry of Oct. 10 (that is, 7 days later) records how I planned to employ the strategies to contact the Pearson International Airport for information of lost luggage:

... I seemed not to know the most appropriate expression to open the conversation when I made a public phone call to request information. So immediately after the exchange of greetings (or rather in the 
course of greeting-exchange) I already felt uneasy (I was thinking whether I was over-polite or too casual). So why not watch how the secretaries in the department make and answer phone calls? (Oct.

10)

Only by practicing such greetings in the authentic communication context did I gradually come to appreciate the social appropriateness in the use of these greetings:

It seems that from the greetings exchanged between the people I had met during the day on the one hand, and myself on the other, I realized the choice of the three greetings correlates with the relations between the speaker:

Prof. X said to me: "Good afternoon." The Chairman of the Department in nodding a smile, said: "Good morning!" The man at the switchboard at OISE: "Good morning!" The social worker in the social community centre said to me: "Good morning!" Elizabeth (my officemate), Joyce the secretary both said "Hi" to me. In exchanging such greetings, I was beginning to feel sure that I really understood the meanings of these words. (Oct. 12)

I am sure that Krashen would say "Look at all the comprehensible input here. Output is leading to more comprehensible input". It seems to me that syntactic processing or focusing on the form of the greeting is the key to the acquisition here. If development of communicative competence is a process of socialization (Candlin, 1986), social interaction is a prerequisite. It is not so much understanding of linguistic data as production of data that counts. In a sense, input can and must be made comprehensible through the learner's own social practice, or to put it another way, by pushing for comprehensible output.

\section{Conclusion: A Comparison Between the Comprehensible Input Hypothesis and the Comprehensible Output Hypothesis}

By emphasizing the role of output in SLA, I do not mean that the role of input should be downplayed. Ellis (1985: p.12) has pointed out: "A central issue in SLA is what role the input plays". Larsen-Freeman (1985) pointed out that "research focusing on input in SLA was begun less than a decade ago" (p.433). She further pointed out that "Hatch and WagnerGough (1976) were among the first to call the attention of SLA researchers to the fact that if we wanted to say something interesting about learner output, we would have to look at the target language input with which the learner had to work". However, the position implied in some research studies seems to go to the other extreme. For instance, Krashen claims that input is the only causal variable in SLA. The role of output is merely engendering more comprehensible input, hence it has no direct bearing on 
the learner's acquisition process. My diary study of self-directed learning has, on the other hand, demonstrated:

(1) Pushing for comprehensible output strengthens a learner's critical awareness of the utterances both (s)he and the interlocutor(s) have produced, hence spurring the learner to greater efforts to seek more negative input or enhancing his or her ability to infer negative input.

(2) Syntactic processing of input is of crucial importance to pushing out incomprehensible output in the course of correcting comprehensible input. I see it as bridging the gap between comprehension and production.

(3) Pushing for comprehensible output is an important means for making the assimilation of comprehensible input possible. Moreover, comprehension of input should be linked to production of output. The use of certain linguistic items in the authentic communication setting fine tunes the comprehension or adds precision to the comprehension of such items. This is especially the case with regard to culture-loaded items.

By way of concluding this paper, it might be useful to make a comparison between Krashen's Comprehensible Input Hypothesis and Swain's Comprehensible Output Hypothesis. Both models regard language acquisition as involving a long process and the learner as having to keep moving from one level of competence to a higher level of competence. According to Krashen's model, if learners understand the language that contains $i+$ 1 structure, they will be able to move up to a higher level of communicative competence. But Swain argues that it is often the case that learners may comprehend input without fully understanding it. Therefore, it is possible that comprehensible input can never be comprehensible enough to the learner in the absence of syntactic processing.

Krashen also argues that it is only when input becomes intake that SLA takes place. But in Krashen's model, how input becomes intake entirely depends on the learner's internal mechanisms, that is to say, a kind of filter that processes input. According to my understanding of Swain's Comprehensible Output Hypothesis, I would venture to hypothesize that intake involves a circular movement from input through the internal mechanism to output, then from output to input. Production of output has a direct bearing on the assimilation of input.

Canale et al (1985) have pointed out that learning through mistakes, learning through doing, learning through observation of an expert and learning through collaboration with an expert are four cornerstones of any serious theory of learning. In this paper, we have seen how pushing for comprehensible output facilitates learning through mistakes. If the "expert" here can be taken to refer to native speakers, this paper has also shown how pushing for comprehensible output teaches the learner how to learn by "observing the expert (eg, observe how native speakers exchange greetings in the telephone situation)" and "working through collaboration 
with the expert (eg. creating a problem of how to express the idea of "taking the call" and asking the native speaker to provide the input)". In short, the Comprehensible Output Hypothesis embraces all four cornerstones of learning.

The Comprehensible Output Hypothesis has marked further maturing of our understanding of second language acquisition. In order to gain a complete understanding of SLA, it would be as misleading to look at the role of input in isolation as it was to look at the role of output in SLA in isolation from that of input. This is one of the theoretical contributions that Swain's thesis has made. On the practical level, it directs our attention to the importance of conscious learning. This is another area that has been somewhat neglected in the past. As Stern (1987) has pointed out, a tendency which is implicit in much of language learning research and language pedagogy is to overemphasize unconscious acquisition processes which are largely beyond the learner's or teacher's control. The importance of these processes is not in question. But that is no reason to think in disparaging terms about the many efforts learners make and must make to come to grips with a new language. Swain's study represents the efforts of the language research community to counter such a tendency.

\section{NOTES}

1. I wish to thank the late Prof. Canale for his generous support and help throughout my diary study. I also wish to thank Prof. Swain for reading my paper and offering many valuable suggestions and insightful comments. Thanks are also due to Peter Tung and Alastair Pennycook who spent many hours discussing the paper with me.

2. Probably the more scientific term should be "progressive aspect". cf. Gregg: 1984.

\section{REFERENCES}

Bailey, K. M. (1980). A Methodological Review of the Diary Studies. In K. M. Bailey, M. H. Long, S. Peck (Eds.), Selected Papers from the Third Los Angeles Second Language Research Forum. Rowley, M.A.: Newbury House.

Canale, M., Be'langer, M., MacRury, K., Ragsdale, R. G. and Mclean, R. S. (1985). Microcomputer software for language arts: survey and analysis (Tech. Rep.). Centre for Franco-Ontarian Studies. Toronto: OISE Press.

Candlin, C. N. (1986). Explaining Communicative Competence: Limits of Testability? In Stansfield, C. W. (Ed.), Toward Communicative Competence Testing: Proceedings of the Second TOEFL Invitational Conference. TOEFL Research Report 21. Princeton, NJ: Educational Testing Service.

Chamot, A. (1987). The Learning Strategies of ESL Students. In A. Wenden \& J. Rubin (Eds.), Learner Strategies in Language Learning. Englewood Cliffs, NJ: Prentice-Hall.

Dickinson, L. (1987). Self-instruction in language learning. Cambridge: CUP. 
Ellis, R. (1985). Understanding Second Language Acquisition. Oxford University Press.

Gregg, K. R. (1984). Krashen's Monitor Model and Occam's Razor. Applied Linguistics, 5(2), 79-101.

Hatch, E. \& Wagner-Gough, J. (1976). Explaining Sequence and Variation in Second Language Acquisition. Language Learning, (Special Issue No. 4).

Higgs, T. V. \& Clifford, R. (1982). The Push Toward Communication. In T. V. Higgs (Ed.), Curriculum, Competence and the Foreign Language Teacher. National Textbook Company.

Holec, H. (1985). Self-instruction in language learning. In P. Riley (Ed.) Discourse and Learning. London: Longman.

Hymes, D. (1974). Foundations in Social Linguistics. University of Pennsylvania Press.

Krashen, S. D. (1978). The Monitor Model for Second Language Acquisition. In R. C. Gingras (Ed.), Second Language Acquisition and Foreign Language Teaching. Cal. U.S.: Arlinton, Va.

Krashen, S. D. (1982). Principles and Practice in Second Language Acquisition. New York: New Pergamon.

Krashen, S. D. (1985). The Input Hypothesis. Longman Group Limited.

Larsen-Freeman. (1985). State of the Art on Input in Second Language Acquisition. In S. Gass \& C. Madden (Eds.), Input in Second Language Acquisition. Rowley, Mass.: Newbury House.

Littlewood, W. (1987). Social and Psychological Influences on Advanced Learners. In J. A. Coleman \& R. Towel (Eds.), The Advanced Language Learner (pp. 11-27). London: The Association for French Language Studies and Scottish Universities' French Language Association.

Long, L. (1982). Native Speaker/Non Native Speaker Conversation in the Second Language Classroom. In M. A. Clark \& J. Handscombe (Eds.), On TESOL '82 (pp. 207-225). Washington, D.C. U.S.: Teachers of English to Speakers of Other Languages.

Morrison, D. M. \& Low, L. (1983). Monitoring and Second Language Learner. In J. C. Richards \& R. W. Schmidt (Eds.), Language and Communication. London: Longman.

Norrish, J. (1983). Essential Language Series. Language Learners and their Errors. London: Macmillan Press.

Rivers, W. (1983). Communicating Naturally in a Second Language. Cambridge University Press.

Rubin, J. (1987). Learner Strategies: Theoretical Assumptions, Research History and Typology. In A. Wenden \& J. Rubin (Eds.), Learner Strategies in Language Learning. Englewood Cliffs, NJ: Prentice-Hall. 
Schachter, J. (1984). A Universal Input Condition. In W. Rutherford (Ed.), Language Universals and Second Language Acquisition. John Benjamins.

Schumann, F. M. \& Schumann, J. H. (1977). Diary of a Language Learner: an introspective study of second language learning. In H. D. Brown, R. H. Crymes, C. A. Yorio (Eds.), Teaching and Learning English as a Second Language: Trends in Research and Practice. Washington, D.C.: TESOL.

Stern, H. H. (1983). Fundamental Concepts of Language Teaching. Oxford University.

Stern, H. H. (1983). Fundamental Concepts of Language Teaching. Oxford University Press.

Swain, M. (1985). Communicative Competence: Some Roles of Comprehensible Input and Comprehensible Output in its Development. In S. Gass \& C. Madden (Eds.), Input in Second Language Acquisition. Rowley, MA.: Newbury House.

Vigil, N. \& Oller, J. W. (1976). Rule Fossilization. Language Learning, 26, 281-295.

Wenden, A. (1986). What Do L2 Learners Know About Their Language Learning? A Second Look at Retrospective Accounts. Applied Linguistics, 7, 186-201.

\section{THE AUTHOR}

Yu Liming was born in Shanghai in 1945. He used to teach English as a Foreign Language to postgraduate Science students. At present he is a doctoral student in The Modern Language Centre of The Ontario Institute for Studies in Education. 